\title{
Peritonealized urachal remnant and obstructive congenital peritoneal band. A case report
}

\author{
L.M. Figueroa, G. Escobar, J. Osorno, M. Acuña, J. Solarte
}

Pediatric Surgery Unit. Surgery Department. Del Valle University. Del Valle University Hospital. Cali, Valle del Cauca (Colombia).

\begin{abstract}
Introduction. Intestinal obstruction as a result of congenital peritoneal bands is rare in surgical practice. It typically compromises the small bowel, and it also has been reported to involve the appendix or a Meckel's diverticulum. However, peritonealized urachal remnant as part of a congenital band is highly infrequent.

Case report. 5-year-old boy presenting with intestinal obstruction related to a peritoneal band from the mesentery to the appendix and a peritonealized urachal remnant, associated with an incidental finding of a Meckel's diverticulum. Diagnosis was achieved laparoscopically. The peritoneal band, the urachal remnant, and the Meckel's diverticulum were resected.

Discussion. Kerkeni's congenital band classification consists of 4 independent groups. This case combines both a band stemming from an embryological remnant and an idiopathic band.
\end{abstract}

Key Words: Anomalous congenital bands; Urachus; Meckel's Diverticulum; Intestinal Obstruction.

\section{REMANENTE URACAL PERITONIZADO Y BANDA PERITONEAL CONGÉNITA OBSTRUCTIVA. REPORTE DE CASO}

\section{RESUMEN}

Introducción. La obstrucción intestinal por bandas peritoneales congénitas es poco común en la práctica quirúrgica. Su ubicación más frecuente compromete el intestino delgado y existen reportes que involucran el apéndice y el divertículo de Meckel, pero que un remanente uracal peritonizado haga parte de una banda congénita es verdaderamente singular.

Caso clínico. Niño de 5 años de edad con cuadro de obstrucción intestinal en el que confluyen una banda peritoneal, que va del mesenterio al apéndice y que se une a un remanente uracal peritonizado, asociado al hallazgo incidental de un divertículo de Meckel. El diagnóstico se definió por medio de una laparoscopia y

DOI: $10.54847 / \mathrm{cp} .2022 .01 .19$

Corresponding author: Dr. Luis Mauricio Figueroa Gutiérrez.

E-mail address: figueroa.luis@ @correounivalle.edu.co

This work has received no funding whatsoever. It was approved for presentation purposes as a poster at the $22^{\text {nd }}$ Colombian Congress of Pediatric Surgery.

Date of submission: Septembrer 2020 Date of acceptance: November 2021 como tratamiento se realizó la resección de la banda peritoneal, del remanente uracal y del divertículo de Meckel.

Discusión. La clasificación de bandas congénitas de Kerkeni comprende 4 grupos independientes, en este caso confluyen una banda derivada de un remanente embriológico junto con el tipo idiopático.

Palabras Clave: Bandas congénitas anómalas; Uraco; Divertículo de Meckel; Obstrucción intestinal.

\section{INTRODUCTION}

Intestinal obstruction (IO) in children may be either congenital or acquired, and due to extrinsic or intrinsic causes. IO as a result of congenital peritoneal bands accounts for $3 \%$ of cases in pediatric surgical practice. These bands are usually difficult to define and classify, and they have an unclear etiology ${ }^{(1,2)}$. Location typically excludes embryological remnants such as the arteries, the vitelline veins, and the omphalomesenteric $\operatorname{duct}^{(2)}$. Congenital bands frequently compromise the small bowel, especially the ileum. According to some reports, they can even involve the appendix or a Meckel's diverticulum ${ }^{(3)}$. One case of peritonealized urachal remnant causing $\mathrm{IO}^{(4)}$ and one case of an urachal cyst connected to a Meckel's diverticulum by means of a fibrous band -with the resulting obstructive symptoms- have been published ${ }^{(5)}$. This is the case of a boy with IO combining a peritoneal band from the mesentery to the appendix and a peritonealized urachal remnant. In addition to the obstructive condition, a Meckel's diverticulum was incidentally found.

\section{CASE REPORT}

5-year-old patient with clinical signs starting 24 hours earlier. He had hyporexia and widespread abdominal pain. At physical exploration, he demonstrated 


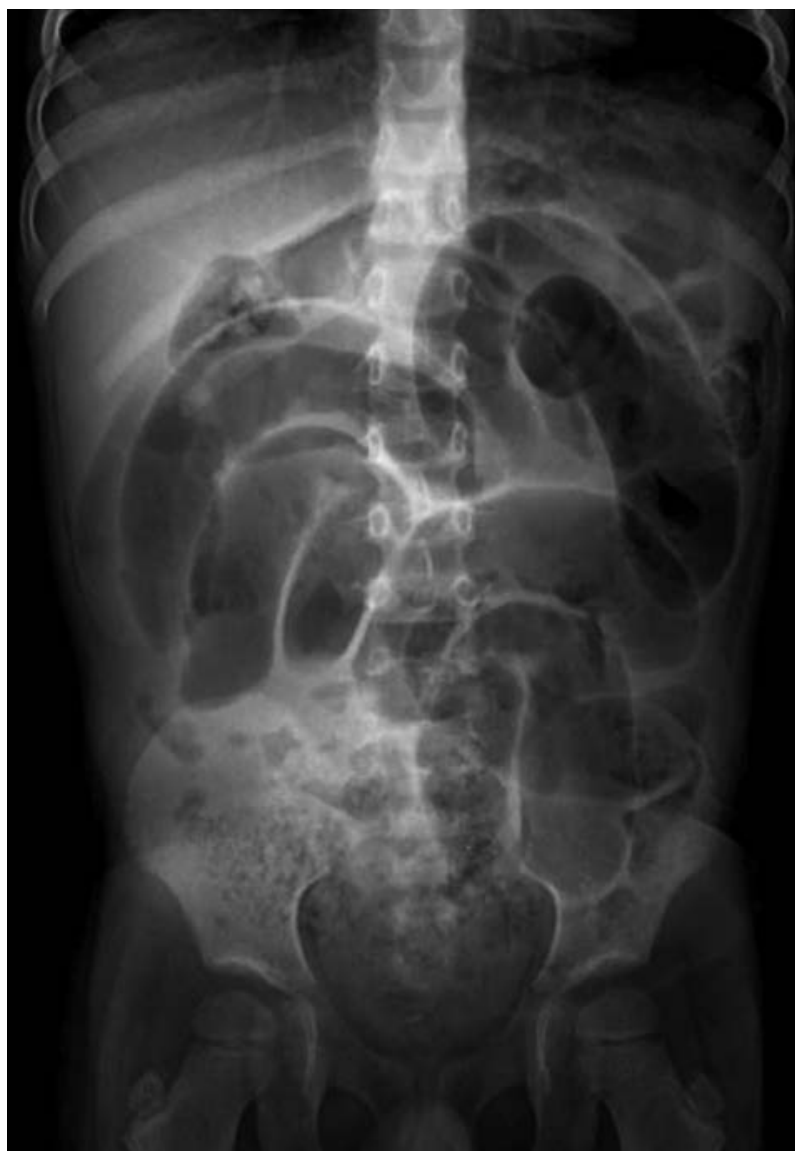

Figure 1. Abdominal X-ray in a prone position with absence of distal gas and small bowel loop distension.

abdominal distension and an acute abdomen. He also had signs of delayed speech as a result of impaired neurological development. Imaging studies including abdominal X-ray (Fig. 1) and abdominal ultrasonography were carried out. No pathological findings were noted in the latter.

Owing to how great abdominal distension was, a nasogastric tube was placed preoperatively. It had a fecaloid drainage, so diagnosis of intestinal obstruction was achieved. A minimally invasive therapeutic laparoscopy was performed using 3 ports. One $10 \mathrm{~mm}$ umbilical port and two complementary $5 \mathrm{~mm}$ ports -one at the left iliac fossa and one at the suprapubic region-were placed using an open technique. Findings included severe dilatation of small bowel loops and a peritonealized urachal remnant (Fig. 2), with a congenital band towards the tip of the -healthy- cecal appendix (Fig. 3) ascending towards the mesentery, and a Meckel's diverticulum $50 \mathrm{~cm}$ away from the ileocecal valve - without alterations. The peritoneal band from the appendix to the mesentery exerted compression on a small bowel loop, thus causing an internal hernia. The peritoneal band, the urachal remnant, and the appendix were resected using the HARMONIC ${ }^{\circledR}$ (Johnson \& Johnson) ultrasonic scalpel. The Meckel's diverticulum was resected, and a video-assisted transumbilical intestinal anastomosis was carried out. Immediate postoperative management was performed at the pediatric ICU. Oral diet was resumed on postsurgical day 4 , and the patient was discharged uneventfully. Outpatient follow-up was uneventful, too. The histopathological report identified well-delimited foci of transitional epithelium without cytological atypia in the abdominal wall sample, consistent with urachal remnant.

\section{DISCUSSION}

The urachus is a vestige of the allantois, which disappears in the fetal period. It is a pre-peritoneal structure connected to the umbilicus through the median umbilical

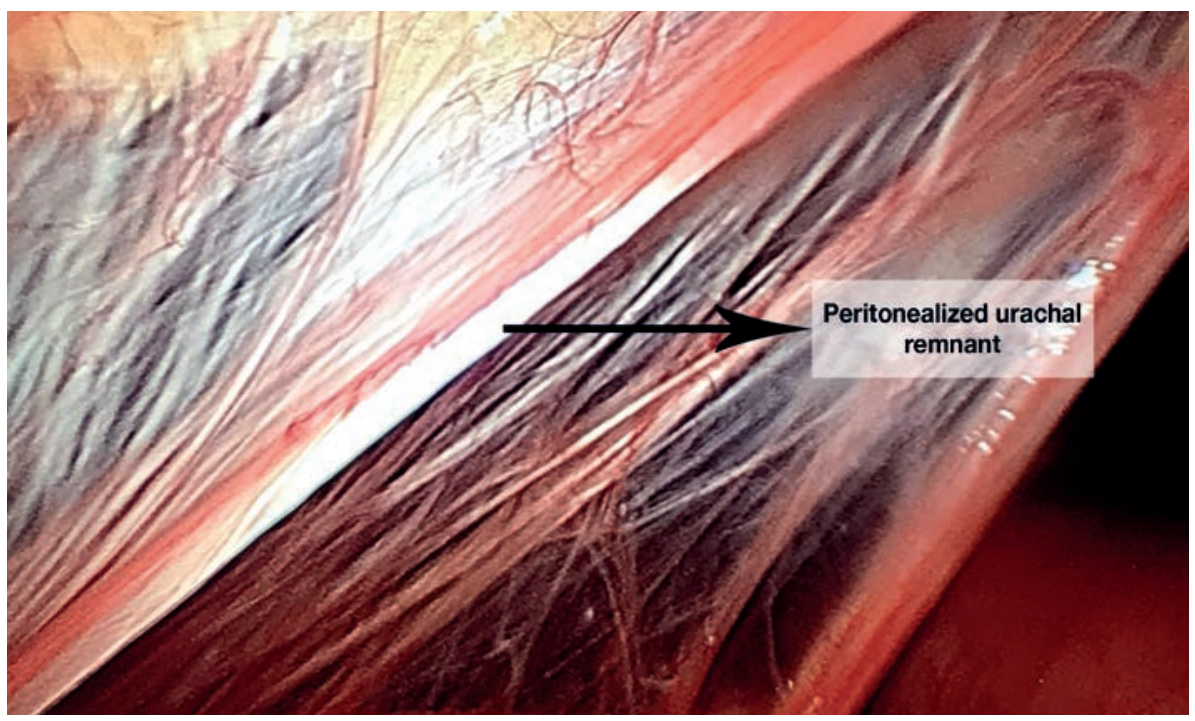

Figure 2. Peritonealized urachal remnant. 


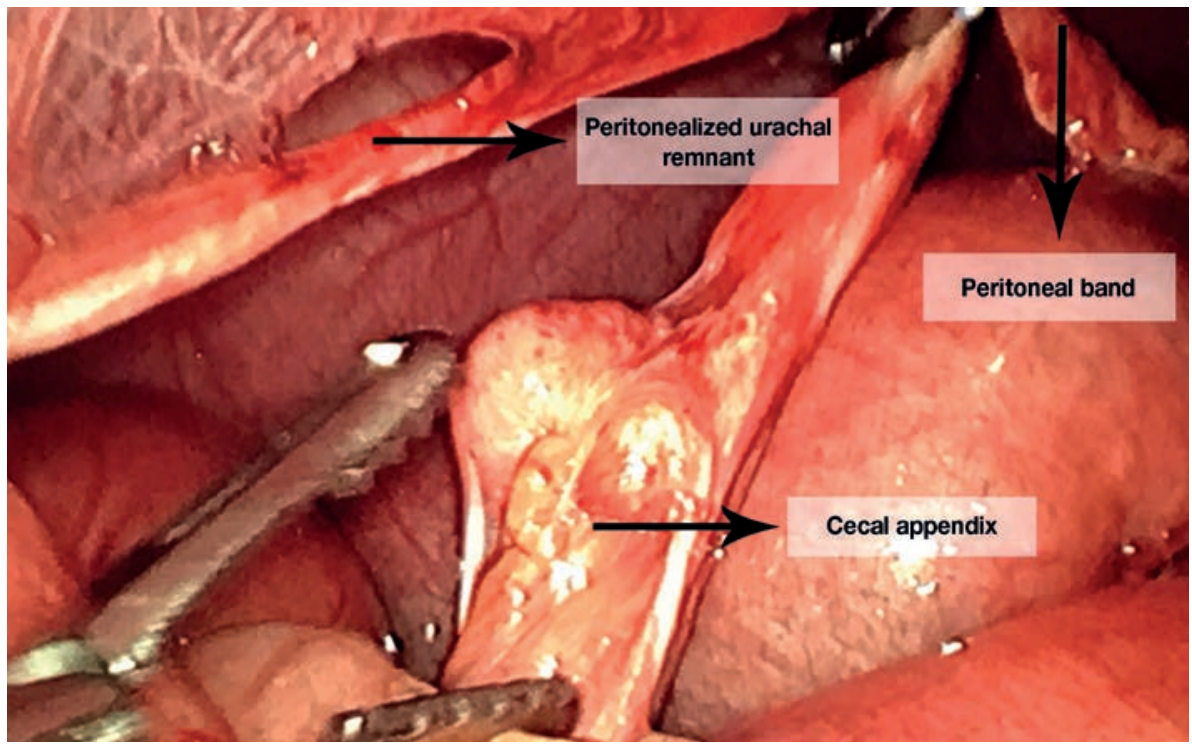

Figure 3. Peritoneal band from the urachal remnant to the appendix, and on to the mesentery.

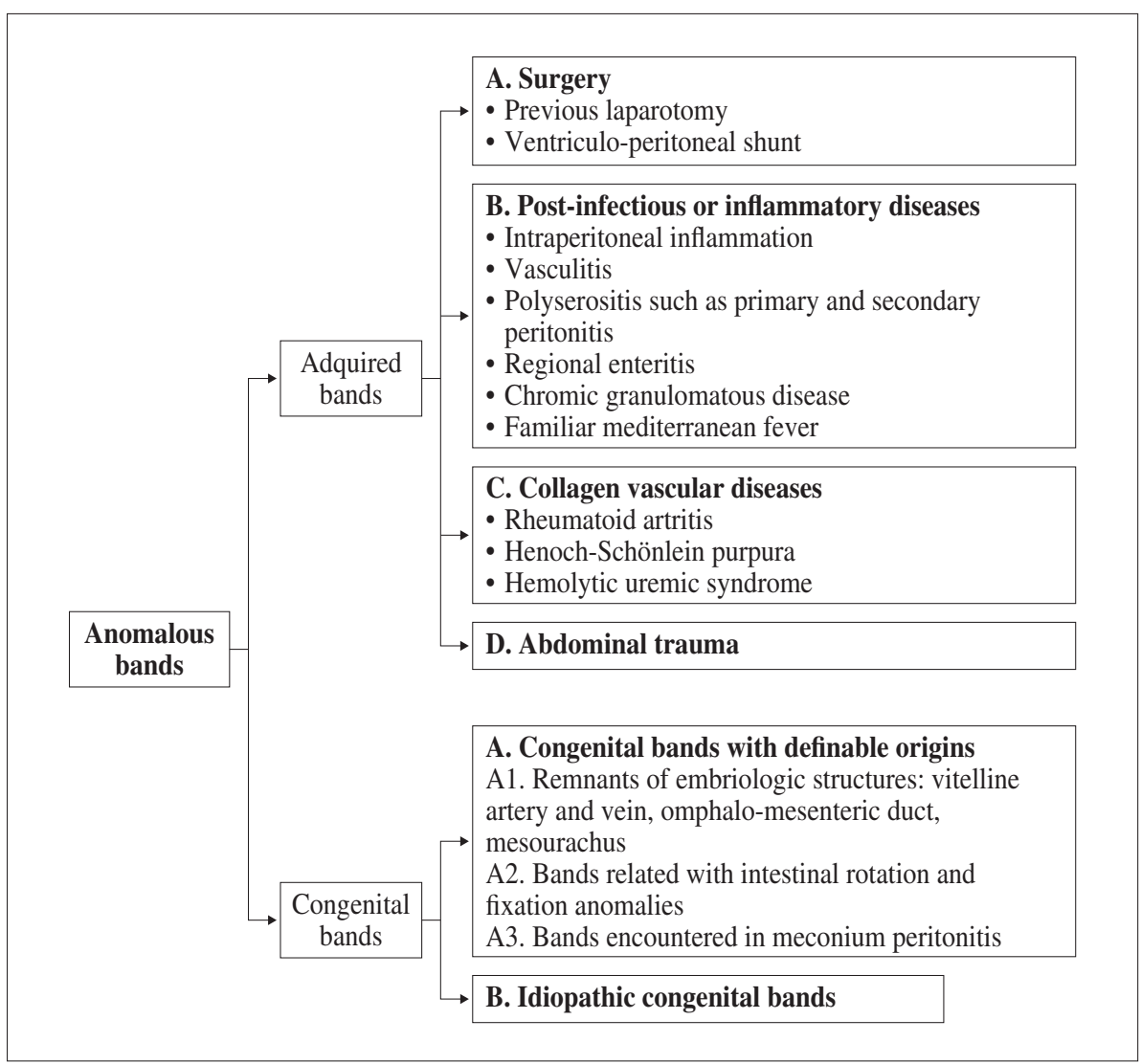

Figure 4. Anomalous band classification. Retrieved from: Kerkeni Y, Aicha B, Hamzaoui M, Idiopathic Congenital Anomalous Bands: About Ten Cases with Systematic Review of the Literature. International Journal of Pediatrics and Adolescent Medicine. 2020.

ligament ${ }^{(6)}$. Disorders in normal urachal development in the fetal period may cause various postnatal clinical signs ${ }^{(7)}$, but persistent peritonealized urachal remnant associated with IO in children has only been described once ${ }^{(4)}$. In addition, congenital peritoneal bands are regarded as a rare cause of IO at differential diagnosis in children ${ }^{(2)}$, and they are typically diagnosed once more frequent causes have been ruled out ${ }^{(8)}$. Since no classification allowing the various anomalous bands to be clearly differentiated was available, Kerkeni et al. ${ }^{\left({ }^{8}\right)}$ (Fig. 4) recently proposed two categories -acquired bands and congenital bands. The latter consist of four categories -bands resulting from embryological remnants, bands associated with malrotation and abnormal intestinal fixation, bands found as a result 
of meconium peritonitis, and idiopathic bands. Our case featured a combination of an idiopathic peritoneal band connected to an urachal remnant.

Finally, the use of minimally invasive surgery in IO cases of unknown origin allows these rare causes to be identified and tackled while enjoying the advantages inherent to this approach, thus avoiding open surgery.

\section{REFERENCES}

1. Etensel B, Ozkisacik S, Döger F, Yazici M, Gürsoy H. Anomalous congenital band: a rare cause of intestinal obstruction and failure to thrive. Pediatr Surg Int. 2005; 21(12): 1018-20.

2. Akgür FM, Tanyel FC, Büyükpamukçu N, Hiçsönmez A. Anomalous congenital bands causing intestinal obstruction in children. J Pediatr Surg. 1992; 27(4): 471-3.
3. Jonatan B, Mariana N, Nurmantu F, Faruk M. Small bowel obstruction due to anomalous congenital bands in children: A case report and literature review. J Pediatr Surg Case Report. 2020; 54. 101389.

4. Haupt GJ, Keitel HK. Intestinal obstruction in a child with a peritonealized urachal remnant. J Pediatr. 1960; 57: 741-3.

5. Garg D, Singh AP, Kothari S, Kumar A. Urachal Cyst, Meckel's Diverticulum and Band, and Urachus. APSP J Case Rep. 2017; 8(1): 8.

6. Martin AJ, McDonald L, Gopal M. Urachal remnant causing umbilical in-drawing during micturition. Ann R Coll Surg Engl. 2018; 100(2): e31-e33.

7. Buddha S, Menias CO, Katabathina VS. Imaging of urachal anomalies. Abdom Radiol (NY). 2019; 44(12): 3978-89.

8. Kerkeni Y, Aicha B, Hamzaoui M. Idiopathic congenital anomalous bands: About ten cases with systematic review of the literature. Int J Pediatr Adolesc Med. 2020; 7(4): 157-60. 